\title{
DA VIDA HUMANA E SEUS NOVOS PARADIGMAS: A MANIPULAÇÃO GENÉTICA E AS IMPLICAÇÕES NA ESFERA DA RESPONSABILIDADE CIVIL*
}

\section{THE LIFE HUMAN BEING AND ITS NEW PARADIGMS: THE GENETIC MANIPULATION AND THE IMPLICATIONS IN THE SPHERE OF THE CIVIL LIABILITY}

\author{
Ana Célia de Julio Santos** \\ Valkiria Aparecida Lopes Ferraro****
}

\begin{abstract}
Resumo: A análise da responsabilidade civil frente às inovações biotecnológicas hodiernas permite o resgate do questionamento acerca da verdadeira função do direito perante a sociedade, principalmente em decorrência da velocidade de informações e das constantes descobertas científicas do Mundo Contemporâneo. Nesse diálogo entre as inovações científicas e a adequação jurídica aos comportamentos delas advindos, depreende-se que o direito não pode mais ficar à espera de casos concretos para regulamentar o assunto. Ao contrário, deve o direito ter o condão de trazer mecanismos assecuratórios eficientes às relações contratuais $\mathrm{e}$ extracontratuais firmadas entre as partes envolvidas, e também da sociedade de forma geral, se pensarmos na proteção da vida das gerações futuras. De uma forma ou de outra, seu objetivo principal continua sendo a proteção dos direitos fundamentais, principalmente o direito à vida digna. Tal tarefa não é fácil, pois o problema encontrado no presente tema é que tampouco a ciência tem resposta quando é inquirida sobre as prováveis conseqüências das pesquisas que envolvem a manipulação genética células vegetais e humanas. Refrear tais pesquisas não se faz oportuno, ante à esperança da cura de doenças e de maior qualidade de vida. Por outro lado, "brincar de Deus" é tarefa preocupante, ante os danos que porventura
\end{abstract}

Artigo extraído da Dissertação de Mestrado, apresentada ao Programa de PósGraduação Strictu Sensu da Universidade Estadual de Londrina, de autoria do primeiro, sob a orientação do segundo.

Mestre em Direito Negocial pela Universidade Estadual de Londrina, Especialista em Direito Público pela Unopar. Docente dos Cursos de Direito da Uninorte e da Univale.

Doutora em Direito Civil pela PUC/São Paulo. Professora do Curso de Direito da Universidade Estadual de Londrina (UEL). Professora do Mestrado em Direito Negocial/Civil da UEL. 
possam causar à humanidade. A legislação global, na grande maioria, não tem apresentado posições favoráveis à manipulação genética de células de embriões. O presente trabalho vem de encontro com as lacunas deixadas pela Lei e as situações que reclama maior atenção: a questão do dano genético e sua reparação civil, principalmente com relação à aplicação, nesses casos, da Teoria Objetiva da responsabilidade civil.

Palavras-chave: Proteção da vida humana. Dano genético. Responsabilidade civil.

Abstract: The analysis of the civil liability front to the nowadays biotechnological innovations allows the rescue of the questioning concerning about the true function of the Rights in the society, mainly in result of the speed of information and the constants scientific inventions of the world contemporary. In this dialogue between the scientific innovations and the legal adequacy to the behaviors is inferred that the Law cannot be waiting to concrete cases prescribe the subject. In contrast, the Law must bring efficient mechanisms to secure the contractual and extracontractual relations between the involved parts, and also to the society, especially if we think about the protection of the life of the future generations. In one way or in another way, its main objective continues being the protection of the basic rights, mainly the right to the worthy life. Such task is not easy, therefore the problem found in the present subject is that neither science has answers when it is inquired about the probable consequences of the research that involves the genetic manipulation in the vegetal cells and human beings cells. Obstruct such research does not become opportune, for the reason that is the hope for the cure of illnesses and bigger quality of life. On the other hand, "to play God" is preoccupying task because the damages that it can cause in the humanity. The global legislation, in the great majority, has not presented positions favorable to the genetic manipulation of cells of embryos. The present research aims to analyze the gaps left for the Law and the situations that greater complains attention: the question of the genetic damage and its recovery, especially with the application of the objective theory of the civil liability.

Keywords: Protection of the human being's life. Genetic damage. Civil liability. 


\section{INTRODUÇÃO}

O homem contemporâneo assiste a uma época de incontestável desenvolvimento técnico-científico, capaz de promover significativas mudanças nos domínios da vida.

Os avanços da biotecnologia alcançam, no mundo, polêmicas discussões filosóficas, sociais, econômicas e jurídicas. $\mathrm{O}$ impacto na sociedade em relação aos avanços trazidos pelo desenvolvimento científico e tecnológico nos campos da biologia, da saúde e da vida, de modo geral, é notável, levando a humanidade a deparar-se com as mais diversas e inusitadas situações até pouco tempo inimagináveis.

Se por um prisma todas essas conquistas trazem na sua esteira renovadas esperanças de melhoria da qualidade de vida dos indivíduos, por outro criam uma série de contradições que necessitam ser criteriosamente estudadas, visando não só ao equilíbrio e ao bem-estar futuro da espécie como à própria sobrevivência do planeta. Por essa razão, as teorias atuais da justiça e da moral trilham por caminhos próprios, diferentes dos da "ética" em seu sentido clássico de uma doutrina da vida correta.

Falar-se em responsabilidade para com a vida implica um retrocesso a princípios bastante antigos, regentes do plano da eticidade humana. Nesse sentido, o pensamento platônico constituiu-se num marco da crença grega tradicional, segundo a qual caberia aos deuses a decisão sobre o destino do homem e de sua vida.

Platão tratou do chamado "mito de Er", onde fez alusão àquilo que estaria reservado ao homem no curso de sua vida. Para ele, o homem não seria livre para escolher entre viver ou não. Mas, esse mesmo homem, dizia o filósofo ateniense, teria a liberdade de escolha entre viver ou não de acordo com a virtude ou sob o domínio do vício. Segundo Platão (2001):

Almas efêmeras, vai começar outro período portador da morte para a raça humana. Não é um gênio que vos escolherá, mas vós que escolhereis o gênio. O primeiro a quem a sorte couber, seja o primeiro a escolher uma vida a que ficará ligado pela necessidade. A virtude não tem senhor; cada um terá em maior ou menor grau, conforme a honrar ou a desonrar. A responsabilidade é de quem escolhe. O deus é isento de culpa. (p. 490).

No texto, Platão afirma que a divindade não teria mais nenhum comprometimento com a responsabilidade humana. Caberia, então, ao próprio homem deliberar sobre suas ações e omissões, responsabilizando-se pelas conseqüências de suas escolhas. 
Então sobre os ombros do homem, para Platão, pesa a árdua tarefa de decidir sobre sua vida, sendo ele o próprio agente ético apto a responder por seus atos.

Vale ressaltar que no pensamento platônico destaca-se a responsabilidade humana sempre projetada para uma dimensão atemporal, ou seja, direcionada para o transcendente, cuja marca seria a eternidade. Platão então buscava a responsabilidade humana sempre direcionada ao destino final do homem.

Já no pensamento filosófico contemporâneo, Hans Jonas representa com louvor os pensadores que se dedicaram a discutir a responsabilidade na era tecnológica, afastando-se dos pensamentos platônicos sobre a responsabilidade em dimensões atemporais e transcendentais, para focar seus argumentos na responsabilidade temporal.

Em linhas gerais, para Hans Jonas, a responsabilidade a ser exigida nos dias de hoje se subsume na temporalidade. Tanto assim que asseverou: ipsis litteris: "O Eros platônico, orientado à eternidade e não à temporalidade, não é responsável de seu objeto. Aquilo ao que nele se aspira é algo superior, que não 'será', senão que já 'é”. ' (JONAS, 1995, p. 209).

Mas isso não significa que tal responsabilidade envolva apenas o mais imediato, mas sim que tal responsabilidade deva ser nas ações de hoje, mas por um mundo vital longínquo, isto é, pela vida que se projeta em direção ao mais distante futuro.

É diante desse quadro que passa-se a tratar, agora, de empreender esforços que orientem e afirmem a conduta responsável de todos aqueles cujas ações possam interferir nos amplos domínios da vida. E essa exigência deve levar em conta o prisma temporal dessa responsabilidade, porque necessariamente envolve o comprometimento com as gerações atuais bem como com as futuras, sendo que pelo termo "futuras" se entenda as mais longínquas que o pensamento imediato seria apto a projetar. Esse é um dos grandes desafios da bioética, indubitavelmente.

Em relação a temas como a proteção jurídica do nascituro, ou do paciente terminal, o direito à vida é um aspecto que não pode ser resolvido de forma voluntarista, seja por parte do legislador, pelos médicos ou pela família. Vislumbrase sob esse ângulo o aspecto moral, ou seja, o momento em que se começa a resolver a questão da vida e da morte sob a ótica moral.

1 "El Eros platónico, orientado a la eternidad y no a la temporalidad, no es responsable de su objeto. Aquello a lo en que en él se aspira es algo superior, que no 'será', sino que ya 'es"'. 
O direito contemporâneo, especialmente o biodireito, enfrenta dificuldades para lidar com essas novas realidades justamente pelo fato de que não se reconhece nas questões da ciência e da engenharia genética uma dimensão moral. A questão emergente, destarte, é a que remonta ao tema da responsabilidade para com a vida.

Desse modo, é imprescindível que, além de se editarem normas regulamentadoras da questão da possibilidade de fazer pesquisas científicas com material genético, mormente o humano, é necessário sejam feitas considerações sobre os reflexos atinentes à essa regulamentação, principalmente em relação à negociação envolvendo o patrimônio genético humano e da responsabilidade civil oriunda dos serviços prestados, das empresas ligadas à terapia genética, sob pena de prejuízos consideráveis a toda a sociedade.

Ao se associar os direitos de personalidade existentes e previstos em nosso ordenamento jurídico com a verificação das formas de negociação que visam ao desenvolvimento e a um dito avanço da sociedade, principalmente no que tange a utilização do corpo humano, percebe-se que limites devem ser impostos.

Nesse diapasão, Francisco Amaral (1999) entende:

[...] é questão preliminar reconhecer-se que o progresso científico deve-se orientar para promover a qualidade de vida individual e social, pessoal e ambiental, mas também que tais descobertas podem causar problemas que o Direito é chamado a resolver, elaborando estruturas jurídicas de resposta que se legitimem pelo respeito aos direitos fundamentais da pessoa humana.

No contexto da regulamentação da questão da manipulação genética, além de se levar em conta principalmente a proteção incondicional à vida, o presente trabalho tratará desses temas atuais envolvendo a questão da proteção da vida em razão dessa nova perspectiva legislativa, em especial a responsabilidade civil dos entes ligados à manipulação genética, por ser imprescindível que se tracem parâmetros à chamada responsabilidade civil objetiva, já que o Código Civil trata da responsabilidade civil subjetiva.

Assim, considerando o homem como centro do ordenamento jurídico, pretende-se interpretar as normas reguladoras do tema, bem como os princípios que norteiam a questão, levando-se em consideração quais sejam os parâmetros legais e doutrinários para chegar-se a uma responsabilização dos entes praticantes de engenharia genética, de forma a manter-se equilíbrio entre o ressarcimento, reparação dos danos e o não cometimento de avanços capazes de ensejar enriquecimento sem causa por parte das vítimas. 


\section{RESPONSABILIDADE CIVIL E O DANO GENÉTICO}

Assunto amplamente debatido entre os juristas, a responsabilidade civil tem extrema importância no mundo moderno, pois a vida é cada vez mais complexa e os avanços tecnológicos contribuem para aumentar o risco de causar dano a outrem ou até mesmo ao meio ambiente.

Em perspectiva histórica, ensina Clayton Reis (2001) que, em tempos passados, o conceito de justiça era primária, observando-se sempre a premissa de que "nenhum ato lesivo à pessoa deveria ficar impune".

Conta o autor, em suas palavras:

[...] o princípio vigente no Código de Hamurabi consistia em coibir-se a violência pela violência. Assim, após o decurso de um longo período da história, os hábitos e costumes dos povos sofreram um natural processo de aprimoramento. A reparabilidade do ato lesivo assenta-se, hoje, no primado de que o causador do dano tem a obrigação de repor as coisas ao seu statu quo ante. (REIS, 2001, p. xvii).

Com o rápido progresso do mundo, houve uma escalada de complexidade nas relações sociais e as melhorias técnicas supervenientes trouxeram benefícios das mais variadas ordens e, com eles, um incremento proporcional nas possibilidades de danos e acidentes.

A sociedade moderna, então, tem se valido de instrumentos a potencializar seus resultados e ganhos. Existe uma farta gama de técnicas publicitárias, de modo a incitar o consumidor a adquirir bens e serviços, fortalecendo a atividade econômica. E isso não pode ser desprezado, pois a sociedade tem se conformado, em nome do progresso, com o aumento do risco a que as pessoas são submetidas para a movimentação da máquina econômica.

Os irmãos Mazeaud e André Tunc (1962, v. 1, p. 11) tratam do tema com propriedade, explicando da importância cada vez maior que adquire a questão da responsabilidade civil, há que se ter em conta uma moderna tendência de as pessoas exigirem segurança. Todos querem estar garantidos contra o risco.

Conforme preleciona Clayton Reis (2001, p. xvii):

[...] nenhum dano perpetrado poderá ficar sem a conseqüente e necessária reparação. Afinal, o equilíbrio da ordem social é preponderante para o Estado, visto que suas atividades são realizadas com o concurso dos agentes que compõem o ambiente societário.

Desse modo, não se pode duvidar que, juntamente com o progresso, vem o incremento da possibilidade do dano. E onde há dano, há espaço para, em tese, 
estar a disciplina da responsabilidade civil, por se tratar de premente equilíbrio da ordem social.

\section{A QUESTÃO DO DANO E O DANO GENÉTICO}

Faz-se necessária a compreensão das diversas modalidades de dano em relação à ciência genética, pois dependendo do tipo de dano (gênico, genômico ou genético), é que se poderá auferir com mais exatidão a gravidade do dano, para posterior análise de reparação ou responsabilidade até em relação às gerações futuras àquele procedimento.

Como primeiro passo, necessário se faz definir o que vem a ser GENE, para que se associe à questão do dano, perfazendo-se a definição de "dano gênico".

Tanto a Lei de Biossegurança (Lei 11.105/2005), quanto o Decreto que a regulamenta (Decreto 5.591/2005) não definem o que seja gene. Mas Goffredo Telles Junior (2004, p. 22-23), trata da definição de gene, afirmando ser "uma fibra do DNA, um seguimento que contém a informação necessária para a elaboração de uma 'receita'de proteína específica”.

A partir desses esclarecimentos, já se torna possível definir o que seja então o chamado "dano gênico" (ANDRADE, 2003, p. 202)2, sendo este o dano causado ao gene, ou seja, o dano causado à unidade hereditária ou genética, situada no cromossomo, que determina as características de um indivíduo.

É o dano relativo ou pertencente ao gene, à unidade funcional do ácido desoxirribonucléico envolvido na síntese de uma cadeia polipeptídica, podendo ser, inclusive, dano causado a qualquer uma das unidades individuais existentes e envolvidas neste processo biológico.

Dependendo do dano, este poderá ou não interferir no processo natural de reprodução e desenvolvimento genético, ou no processo original de transmissão

\footnotetext{
${ }^{2}$ Note-se que o autor ainda explicita o entendimento do geneticista Dr. Salmo Raskin, que em matéria intitulada "A conquista do Genoma Humano", veiculada no O Estado do Paraná, 25.02.2001, alega "não ser o gene ainda a menor partícula a ser considerada neste processo, uma vez que ele mesmo é composto de partículas menores denominadas de exons e instrons. Nas palavras do geneticista citado: "os primeiros são os que verdadeiramente transmitem informações e codificam proteínas, são cerca de 5\% dos 3 bilhões de letras (ADCG)* da seqüência genética, os demais não produzem proteínas, seriam trechos ainda sem sentido, verdadeiros fósseis genômicos, trazendo informações a princípio arcaicas e sem qualquer sentido hoje em dia, devendo ter alguma função reguladora, ainda não descoberta, não se tratando como a princípio se pensava, de simples lixo genético. *ADCG: adenina, genina, citosina e guanina.
} 
dos caracteres hereditários de um indivíduo. Então, se o dano for causado em gene de células germinativas, ele será transmitido para outras futuras gerações o que, destarte, o transformará também em dano genético ${ }^{3}$.

Mas, se o dano for causado somente em um gene de células somáticas, este dano não será transmitido para futuras gerações, e morrerá com o indivíduo, se constituindo um dano gênico puro.

Assim, dependendo da abrangência do dano, poder-se-á criar celeuma a respeito das possibilidades de danos ou prejuízos que alguns tipos de tratamentos possam causar, e, sob a ótica contratual, se fizer constar tais detalhes de possíveis danos futuros no termo de consentimento informado dos pacientes, para a autorização ou não desse tratamento.

${ }^{3}$ Rosaldo Jorge de Angrade cita em seu artigo (2003, p. 203-205), um exemplo de dano gênico: "um bebê criado pelo método de transferência de citoplasma irá portar genes de três pessoas diferentes. Quem poderá garantir que o DNA mitocondrial da mãe doadora não irá influenciar futuramente na criança, de modo negativo, não esperado pelos pais biológicos? Eis a matéria citada: "Cientistas dos EUA criam bebê transgênico. (Jornal O Estado do Paraná de 06.05.2001. Nova Jersey - (Das agências) - Dois bebês americanos de mais ou menos um ano têm 'três pais'. Foram gerados no Institute for Reproductive Medicine and Science of St Barnabas, em Nova Jersey, por um método chamado transferência de citoplasma. Em suas células, geneticamente modificadas, há DNA de três pessoas. Um feito, comprovado em laboratório, que pode revolucionar o campo da reprodução assistida e promete suscitar discussões acaloradas sobre ética. A técnica usada por Jacques Cohen, que liderou o experimento, não é nova. Desenvolvida em meados dos anos 90, ela chegou ao Brasil, trazida pelo próprio Cohen, há dois anos e, desde então, possibilitou o nascimento de 30 crianças no País. Consiste em injetar parte do citoplasma de uma mulher jovem no óvulo de outra mulher com dificuldades para ter filhos. 'É uma forma de rejuvenescer o óvulo', disse José Franco Júnior, professor de Ginecologia da USP e diretor do Centro de Reprodução Humana da Maternidade Sinhá Junqueira, em Ribeirão Preto (SP). Cientistas acreditam que uma das causas da infertilidade sejam defeitos na mitocôndria (estrutura presente no citoplasma da célula e envolvida na respiração celular). Ao receber citoplasma de uma mulher jovem, portanto, o óvulo degenerado teria uma mitocôndria sadia, devolvendo a fertilidade à mulher mais velha. Ao fazer testes de identificação genética em duas crianças nascidas nos EUA por aquele método, Cohen constatou que as células dos bebês tinham três DNAs diferentes: um vindo da mãe, um do pai e o outro da mitocôndria (única estrutura fora do núcleo celular que contém genes) da doadora. Os cientistas não sabem qual a função do DNA mitocondrial (transmitida apenas pelas mulheres), mas suspeitam de que tenha influência no DNA nuclear, que determina todas as características do indivíduo, inclusive suscetibilidade a doenças.” 
E mais, quais as dimensões que poderão chegar a exigência de ressarcimento de danos e indenização por responsabilidade civil?

O conceito estabelecido no artigo $8^{\underline{a}}$ da Declaração Universal do Genoma Humano não se aplica ao dano gênico, mas sim ao dano genômico, pois declara que "todo indivíduo terá o direito, segundo a lei internacional e nacional à justa reparação por 'danos sofridos' em conseqüência direta e determinante de uma intervenção que tenha afetado o seu genoma”. (Grifo nosso).

Da mesma forma como fora tratado o chamado "dano gênico", trataremos, a priori, de definir o que seja o conceito de genoma, mormente o genoma humano ${ }^{4}$, razão do presente estudo. genoma humano, segundo o Dicionário AurélioSéculo XXI, "é a constituição genética total de um indivíduo ou zigoto".

Maria Helena Diniz (2002, p. 382), conceitua o Genoma Humano partindo de definição de Jaime Espinosa e Elio Sgreccia do que seja a engenharia genética, senão vejamos:

[...] transferência de certas informações genéticas para as células de um organismo. Tais informações advêm de fonte diversa da carga genética da célula onde introduzida e são responsáveis pelas novas características nesta ou no indivíduo receptor. Esse conjunto de informações contidas nos cromossomos de uma célula denomina-se genoma, e o DNA [ácido

${ }^{4}$ O Dr. Salmo Raskin, professor da PUC-PR, médico geneticista, em palestra proferida, em setembro de 2000, na sede da Associação Médica do Paraná, em Curitiba-PR, assim conceituou o que seria genoma humano: "O nosso material genético está presente em todas as células do nosso corpo. São cerca de 100 trilhões de células. Em cada uma dessas células nós temos um núcleo que carrega um pacote de material genético, separado nos 23 pares de cromossomos. Espalhados por 23 pares de cromossomos nós temos algo em torno de 100 mil genes. Em cada cromossomo nós temos mais ou menos 4.000 genes. Para chegar a um gene temos que entrar dentro de uma dos 100 trilhões de células do corpo; entrar no núcleo dessa célula; escolher mil avos e entrar dentro desse quarto mil avos. Ao fazer isso nós vamos encontrar uma seqüência das famosas letrinhas da bioquímica ADCG (adenina, genina, citosina e guanina). A partir daí teremos chegado à identidade genética de um organismo. Dentro do núcleo de cada célula existem cerca de 3 bilhões dessas letrinhas. Essa seqüência de bases nitrogenadas é que compõe o nosso Código Genético a que denominamos de GENOMA HUMANO e que contém toda a nossa herança genética, transmitida de geração em geração. Quando fizermos isso é que realmente iremos descobrir a identidade genética de um organismo. Portanto, 'GENOMA HUMANO' é nada mais nada menos que a seqüência de 3 bilhões de bases nitrogenadas que compõem nosso Código Genético.” (ANDRADE, 2003, p. 206-207). 
desoxirribonucléico] é o portador da mensagem genética, podendo ser imaginado como uma longa fita onde estão escritas, em letras químicas, os caracteres de cada ser humano, sendo, por isso, sua imagem científica.

Assim, pode-se conceituar o dano genético como sendo o dano causado ao genoma, à constituição genética total de um indivíduo ou zigoto (ANDRADE, 2003, p. 207). Dano causado não a um gene específico e isolado, mas a todo o conjunto de genes, ou a um grupo representativo deles onde houvesse o comprometimento da constituição genética total de um indivíduo.

Seria, pois, um dano poligênico, e não dano gênico; uma subespécie do dano genético, já que altera a constituição genética total de um indivíduo, necessariamente interferindo em células germinativas, afetando assim o processo original de reprodução.

É exatamente desse tipo de dano que trata o artigo $8^{\underline{a}}$ da Declaração Universal do Genoma Humano; é esse o dano pelo qual se objetiva tipificar, quando prevê o direito à justa reparação por danos sofridos em conseqüência direta e determinante de uma intervenção que tenha afetado o "genoma" de um indivíduo.

Diz-se genético o que seja relativo ou pertencente à gênese, geração. Tudo o que seja relativo à genética. A Genética, por sua vez, é um ramo da biologia que estuda as leis da transmissão dos caracteres hereditários nos indivíduos, e as propriedades das partículas que asseguram essa transmissão.

Então, dano genético (ANDRADE, 2003, p. 208) é o dano causado ao processo original de transmissão dos caracteres hereditários, quer resultantes do manuseio e da aplicação das técnicas de engenharia genética; quer de outros fatores que interfiram de algum modo neste processo.

Quanto à classificação do dano genético, pode-se dizer que é uma espécie do gênero dano, da qual deriva a subespécie dano genômico, podendo também, em caso específico, derivar, como subespécie, o dano gênico, posto que, tanto o gene (individualidade, quando se tratar de células germinativas) quanto o genoma (totalidade de genes) fazem parte do processo de transmissão dos caracteres hereditários de um ser.

O dano genético é, por sua natureza, classificado como dano subjetivo ${ }^{5}$, ou seja, dano à pessoa; aquele que atenta contra o ser humano, em qualquer etapa do seu desenvolvimento existencial. Mas também podem ocorrer situações em que o dano genético possa ser classificado como dano patrimonial ou material.

${ }^{5}$ A autora Luciana Mendes Pereira Roberto em sua obra "Responsabilidade Civil do Profissional de Saúde \& Consentimento Informado se refere à classificação do dano também como subjetivo, ipsis litteris: “[...] Há, além desses, os danos pessoais e não- 
A doutrina contemporânea têm entendido que a palavra "patrimônio" significa não só bens de família, dote, herança paterna, bens, mas também se refere ao patrimônio como sendo o conjunto de bens culturais ou naturais, de valor reconhecido para determinada localidade, região, país, ou para a humanidade, passíveis, assim, de proteção, como por exemplo, através de tombamento.

Então, a idéia de posse coletiva como parte do exercício da cidadania inspirou a utilização do termo patrimônio para designar o conjunto de bens de valor cultural que passaram a ser propriedade da nação, ou seja, do conjunto de todos os cidadãos.

Embora muito se fale atualmente em "patrimônio genéticos, leva-se a entender que os danos a ele causados, aqui tanto faz se tratar de dano gênico, genômico ou genético, embora se constituam de patrimônio natural de interesse da humanidade, num primeiro momento, não se trata de danos objetivos, materiais (patrimoniais), mas sim de danos subjetivos, posto que, como já dito, são uma espécie de dano à pessoa.

Apesar de não ser tema aqui analisado, não se pode esquecer dos chamados Organismos Geneticamente Modificados (OGMs), também tratados pela Lei de Biossegurança, os quais podem ser também ter caráter patrimonial, sendo assim passíveis de apreciação, quantificação e valoração econômica.

Ressalte-se que o genoma, quer seja humano, quer seja animal ou vegetal, em seu estado natural, pode ser apenas objeto de dano moral. Entretanto, se esse mesmo genoma for modificado geneticamente, pode ser objeto também de um dano material, posto que sujeito de apreciação financeira, até mesmo alvo de patenteamento, sendo então de estado variável conforme seja natural ou modificado.

Mas desde já se salienta que no estado atual do direito, a reformulação contemporânea jusfilosófica e ideológica da responsabilidade civil vem informar que este é um momento de gradual superação do caráter individualista do direito privado que permeou os séculos XIX e XX, sendo que a nova tendência é a de privilegiar o princípio do personalismo ético, em que a pessoa é a destinatária

pessoais, se produzidos em pessoas ou coisas; o dano real, sendo o prejuízo que o lesado sofreu, que pode ser analisado patrimonial ou não-patrimonialmente, e o dano de cálculo, que é a expressão pecuniária do prejuízo, pendente de avaliação; os danos presentes e os danos futuros (desde que previsíveis), se já verificados ou não no momento da data da fixação da indenização.” (ROBERTO, 2005, p. 182, grifo nosso). 
primeira da ordem jurídica, e, desta forma, deverá ser indenizada amplamente pelos danos que lhe forem causados, quer sejam morais ou patrimoniais, de forma isolada ou simultânea.

Nas palavras poéticas de Giselda Hironaka (2001):

Mudaram os métodos, mudou a filosofia, mudou a história. Conseqüentemente, muda a mentalidade de um povo; esta mudança, hoje, globaliza-se e inunda os sistemas de responsabilidade civil de todo o mundo, que estejam ligados às mesmas raízes de configuração que desenham e reescrevem os sistemas ocidentais de direito.

Afinal, no passado, o homem não conheceu, além do fenômeno da mecanização desvairada, o desastre da deterioração do ambiente, o desespero da contaminação por AIDS, o descalabro do desmedido avanço das biotecnologias e suas conseqüências, para citar apenas alguns desses novos perfis de danos capazes de comprometer prejudicialmente os limites da dignidade e do patrimônio de suas vítimas.

Mais um século na vida dos homens se escoa e, com ele, renovar-se-á o milênio. Há pelo menos dez lustros a urgência dessa nova realidade grita por novas soluções, fundada no velho adágio segundo o qual os fatos atropelam o direito. A reformulação jurídica que se reclama vem principiada por reformulações de ordem filosófica e de ordem ideológica, principalmente. Há um sentir distinto do sentir passado. Há uma mentalidade impregnada pelo crivo social que admite a valorização da pessoa humana antes de qualquer outra consideração. Há a preocupação de não deixar o dano sem indenização e, por isso, minimizar, ao máximo, o número de vítimas irressarcidas entre nós, que queremos, ansiamos e propugnamos por uma sociedade mais justa e menos desigual. (p. 219).

Em síntese, a responsabilidade civil hoje, muito pouco guarda de semelhança com a responsabilidade de anos atrás. Nas últimas décadas, o foco da responsabilidade civil passou de prova do dano e culpa, para o interesse primordial da situação da vítima e seu direito de ser ressarcida.

\section{OS REQUISITOS DE CERTEZA E ATUALIDADE EM FACE AO DANO GENÉTICO}

Num primeiro enfoque da problemática trazida na questão da reparação de danos causados por práticas de engenharia genética, mormente em relação à certeza e atualidade do dano, estes são, à priori, referentes ao dano genético; ou seja, para que haja indenização ou obrigação de reparar, há que existir primeiramente o dano genético.

Tal assertiva merece considerações acerca da necessidade de efetivo evento 
ocorrido para gerar então a responsabilidade, principalmente das empresas que trabalham com engenharia genética.

Este dano deve ser quantificável para poder ser objeto da indenização, ou reparação. Isso vale também para o dano moral, o qual precisa ser localizado e quantificado normalmente através do pretium doloris, ou seja, do valor atribuível à dor da vítima.

Também surge como requisito essencial que o dano seja "atual". Aqui reside um problema, ao afirmar-se que os danos futuros, especialmente em questões ligadas à engenharia genética, por serem incertos, são ou não objeto de indenização.

Para dirimir tal questionamento, referem-se os doutrinadores aos princípios do personalismo ético, da autonomida e da beneficiência, levando-se sempre como fato primordial o respeito à pessoa humana, e, via de conseqüência, com entendimento que tal indenização tem de ser a mais ampla possível, abrangendo inclusive danos futuros, calcada na Teoria do Risco Integral ${ }^{6}$.

Mas nem só da Teoria do Risco Integral pode sobreviver a questão da responsabilidade das empresas que trabalham com engenharia genética. Francisco Vieira Lima Neto (1997) aduz sobre o tema que:

Ora, esta linha de raciocínio não é suficiente para justificar a obrigação legal desta empresa indenizar acidentes que tenham decorrido de fato da natureza, pois este sempre foi uma típica excludente de responsabilidade. Com efeito, o fato natural rompe o nexo causal entre ação da empresa e evento danoso, passando a ser, ele próprio, a ação causadora do acidente. A única maneira de se justificar a responsabilidade da empresa, então, é demonstrar que o legislador ao votar uma lei que obriga empresas a indenizarem independentemente de culpa, além de adotar a Teoria Objetiva da Responsabilidade e a Teoria do Risco, opta por uma outra Teoria do Nexo Causal; ou seja, o legislador abandona a Teoria da Causalidade Adequada que é a do Código Civil, típica da Responsabilidade Subjetiva, para adotar a Teoria da Equivalência das Condições ("condition sine qua non"), mais apropriada para a Responsabilidade Objetiva, por ser a que mais se adapta ao interesse social de imputar responsabilidades às empresas mesmo se o acidente tiver sido causado, imediatamente, por um fato natural. (p. 102).

${ }^{6}$ Por Teoria do Risco Integral entende Francisco Vieira Lima Neto: "se uma empresa dispõe-se a iniciar uma atividade lucrativa e arriscada, sujeita-se aos bônus e também aos ônus, dentre os quais estaria a sua obrigação de indenizar se qualquer prejuízo causasse com sua atividade". (LIMA NETO, 1997, p. 102). 
Assim, a responsabilidade em caso fortuito também existirá, já que estabelecida por lei. Não se terá que indagar se o dano ocasionado foi devido à defeito de aparelhos do laboratório, à culpa dos manipuladores ou a força maior.

Observa-se, entretanto, um único inconveniente: o de se chegar à situação do chamado "regressum ad infinitum", ou seja, a regressão ao infinito à procura de causas, pois na Teoria da Equivalência das Condições, todos quanto concorrem física ou materialmente para o evento é responsável pelo evento danoso.

Mas excluir a responsabilidade da empresa que trabalha a engenharia genética quando o dano é causado por fato da natureza é dirigir-se contrariamente à moderna concepção de Responsabilidade Civil e permitir que uma atividade que manipula a vida possa ser tida como menos perigosa do que a atividade poluidora, pois a Lei $6.938 / 81$ prevê a responsabilidade objetiva em face dos danos causados ao meio ambiente.

Diante de tais fatos, conclui-se que quando o Artigo 20 da lei 11.105/2005 determina que "os responsáveis pelos danos ao meio ambiente e a terceiros responderão, solidariamente, por sua indenização ou reparação integral, independentemente da existência de culpa", traz como elemento essencial da responsabilidade civil o desenvolvimento da atividade de engenharia genética e não a ação danosa ligada direta ao dano ocorrido.

De forma contrária à adoção da teoria da equivalência de condições para a responsabilidade civil objetiva das empresas que trabalham com a engenharia genética, mormente por fatos da natureza, posiciona-se Aline Mignon de Almeida (2000, p. 132):

Entendemos ser extremada a posição de adotar a teoria da equivalência das condições nos casos que envolvam a engenharia genética porque levaria muitas vezes a situações absurdas. Ademais, tornaria a área bem menos atrativa devido ao alto risco. Fazer uma empresa indenizar danos ocorridos devido a fatos da natureza não é coerente pois, se formos analisar, o Estado também teria contribuído para o sinistro, dando permissão para o exercício da atividade de engenharia genética. Achamos que o caso fortuito e a força maior devem sempre ser excludentes da responsabilidade.

A autora completa seu pensamento sugerindo que mister se faz com que seja exigido dos empresários do ramo da engenharia genética o emprego máximo de segurança à população, não sendo suficiente a diligência normal para excluir a responsabilidade. 


\section{ALGUNS ASPECTOS PARA PREVENÇÃO DO DANO}

Preciosa é a contribuição de Rosvaldo Jorge de Andrade (2003), quando ensina que "não basta saber o que é dano para que o mesmo possa meramente ser remediado. É necessário, pois, também que seja adotada uma política preventiva, que é muito mais saudável do que a difícil jornada da reparação pura e simples” (p. 212).

Assim, medidas preventivas deverão ser estimuladas e até regulamentadas não só no sentido das práticas diretas, mas também das indiretas, bem como nas condições de ambiente da pesquisa e dos próprios fatos da natureza, ou seja, os elementos externos que também contribuem para o ocasionamento de danos.

Interessante se faz trazer à lume a questão da inexistência de um mecanismo de seguro capaz de gerar uma indenização mínima às vítimas, dado ao elevado risco das atividades das empresas de engenharia genética.

Frise-se que tais atividades vão desde a manipulação de simples células, sem qualquer caráter perigoso eminente ao homem e ao meio ambiente, como também a de vírus altamente letais e patogênicos, para ambos. Daí a necessidade de se vislumbrar algum sistema acautelatório.

Seria uma espécie de mecanismo de garantia coletiva, um tipo de seguro, podendo ser obrigatório ou facultativo, disponibilizado ao agente. Se asseguraria a reparação do dano causado por uma fonte de riscos determinada, independentemente da discussão acerca da culpabilidade individual do autor do dano.

Por enquanto, segundo João Monteiro de Castro:

[...] tal matéria é objeto de vivo debate e não há, ainda, iniciativa de montagem desse sistema de garantia do risco médico no caso de utilização de técnicas de engenharia genética. Enquanto não vem um sistema nos moldes do proposto, os médicos, clínicas e hospitais vêm aderindo ao seguro de responsabilidade civil e esta ainda fundada na culpa, provada ou presumida em certos particulares casos, mediante o pagamento de prêmio proporcional ao capital segurado. (2005, p. 161-163).

Seria, pois necessária a formação desse mecanismo de administração de riscos e controle de qualidade das empresas, hospitais e clínicas que trabalham com manipulação genética. Segundo Miguel Kfouri Neto (2002), "alguns hospitais brasileiros têm adotado o método de risk management, ou controle de riscos, que nos Estados Unidos assume grande importância para reduzir o custo do seguro". (p. 419-420).

Partiria-se da mesma base informativa dos hospitais, mas seriam atinentes em especial a tratamentos com manipulação genética, sendo realizadas em hospitais, clínicas, entre outros. Levantariam-se os dados estatísticos das situações 
consideradas problemáticas em relação à possível responsabilidade civil, e, depois de analisados os dados, partiria-se à adoção de medidas preventivas que seriam avaliadas pelo resultado obtido na diminuição dos índices negativos.

\section{CONCLUSÃO}

O direito contemporâneo está enfrentando novos problemas, que nem sempre são resolvidos pelos instrumentos tradicionais de proteção à vida. Os estudos de Ciências Biomédicas, Bioética, Filosofia e Direito estão cada vez mais amplos, em virtude dos avanços da tecnologia, da medicina e das investigações que surgem na ciência contemporânea. Tais pesquisas levam ao conhecimento e exame dos resultados das investigações e suas aplicações em seres humanos.

A implementação das conquistas biotecnológicas afeta, num primeiro momento, a autocompreensão como seres que agem de forma responsável e de que modo isso se dá, pois depende da autocompreensão de cada sujeito o modo como desejarão utilizar desse novo caminho de decisões; de maneira autônoma, segundo considerações normativas insertas na formação democrática da vontade, ou de maneira arbitrária, em razão de suas preferências subjetivas, que serão satisfeitas pelo mercado.

A priori, deve-se ter em vista que pensar em questões trazidas pela genética é pensar na dignidade do ser humano. Assim, as escolhas feitas pela sociedade brasileira que surgirão dever-se-ão adequar-se sempre com tal princípio. Mas indubitavelmente, desafios sempre virão, dia a dia, para que se reflita sobre o tema.

Imperioso se faz que se realce o interesse e o controle crescente do desenvolvimento da pessoa, com respeito à ciência, seus limites e sua transformação. No mundo contemporâneo, a pesquisa genética e a biotecnologia estão a demandar a reavaliação de valores e a revisão do quadro normativo. $\mathrm{O}$ ambiente jurídico requer uma visão crítica voltada não somente para o apontamento de imperfeições, mas também com a meta de se formar um novo ponto de vista constitucionalcivilista, que se coadune com a modernidade.

O direito civil, também no contexto da nova ordem contratual e no que tange à responsabilidade civil e reparação de danos, deve estar apto à proteção da vida humana em sua totalidade, pacificando os conflitos surgidos na sociedade.

O jurista somente conseguirá desvencilhar-se do emaranhado de dúvidas legais trazidas pelas inovações biotecnológicas se estiver disposto a deixar de lado os paradimas civilistas-positivistas do século passado, e perceber que o verdadeiro papel do Direito é adequar o mundo jurídico aos ditames interdisciplinares, organizando, destarte, a sociedade com apoio à ciência genética. 
A ciência não é funesta e sim o comportamento humano, ou seja, o que o homem pode fazer com descobertas científicas. Por isso é necessário encontrar limites, estabelecer distinções entre bem e mal no uso das novas tecnologias, aplicando-se o direito não apenas para inscrever as proibições, mas também para reconhecer e absorver as transformações operadas na vida, consolidando os pilares éticos orientadores das condutas relativas ao avanço da ciência.

A preocupação constante de se controlar a tecnologia tem reaproximado a ética e o conhecimento, ou seja, os valores morais e a ciência. Essa interação sempre será permeada pelo Direito, consolidando conceitos bioéticos já existentes, bem como dando novo sentido aos que forem atingidos pelas descobertas técnicocientíficas.

A questão crucial se dá exatamente na busca de um relacionamento adequado e eficiente dos fatos, atos e negócios jurídicos, sendo que estes ocorrem num contexto temporal, para os quais sempre há uma norma jurídica, ou seja, uma regra de conduta e de decisão, uma previsão normativa e uma conseqüência jurídica, e a revolução biotecnológica.

O direito deve estabelecer uma relação eficiente dos possíveis ou prováveis danos causados pela engenharia genética e sua reparação civil, tendo em vista o fator previsibilidade de malefícios futuros que, entre outros, e como em toda ciência natural, tem sua evolução marcada por saltos abruptos e hoje paradoxalmente ininterruptos.

Os princípios do personalismo ético, da autonomia e da beneficência estão servindo de parâmetro para as respostas que o intérprete do direito (cientista jurídico) está adotando frente aos novos desafios da pós-modernidade do direito diante dos avanços da evolução científica.

A reparação dos danos causados por empresas de engenharia genética obedece à teoria da responsabilidade objetiva, independente da prova de culpa, e que se faz necessário pensar-se na prevenção de tais danos, bem como na criação de mecanismos de seguro para melhor atender o aspecto social de proteção das vítimas.

Caberá a toda a comunidade jurídica o papel de contribuir para fomentar o debate sobre um Código de Engenharia Genética e difundir o conhecimento dele produzido para que seja acessível a todos, leigos e acadêmicos, com o escopo principal de equilíbrio e respeito à dignidade humana. 


\section{REFERÊNCIAS}

ALMEIDA, Aline Mignon. Bioética e biodireito. Rio de Janeiro: Editora Lúmen Juris, 2000.

AMARAL, Francisco. Direito civil - introdução. 4. ed. rev., atual. e aum. Rio de Janeiro: Renovar, 2002.

. O poder das ciências biomédicas: os direitos humanos como limite. In: CARNEIRO, Fernanda (Org.). A moralidade dos atos científicos: questões emergentes dos comitês de ética em pesquisa. Rio de Janeiro, Fiocruz, 1999.

ANDRADE, Rosaldo Jorge. Engenharia Genética: dano genético e responsabilidade civil. In: BARBOZA, Heloisa Helena; MEIRELLES, Jussara M. L.; BARRETO, Vicente de Paulo. (Org.). Novos temas de biodireito e bioética. Rio de Janeiro: Renovar, 2003.

BARBOZA, Heloisa Helena; BARRETO, Vicente de Paulo. (Org.). Temas de biodireito e bioética. Rio de Janeiro: Renovar, 2001.

BARBOZA, Heloisa Helena; BARRETO, Vicente de Paulo; MEIRELLES, Jussara M. L. de. (Org.). Novos temas de biodireito e bioética. Rio de Janeiro: Renovar, 2003.

BARROS, José Manoel de Aguiar. Revolução biotecnológica e regulação jurídica. In: - Filosofia do Direito: ensaios. São Paulo: J. de Oliveira, 2004.

CASTRO, João Monteiro de. Responsabilidade Civil do Médico. São Paulo: Editora Método, 2005.

DIAS, José de Aguiar. Da Responsabilidade Civil. Rio de Janeiro: Forense, 1994.

DINIZ, Maria Helena. O estado atual do biodireito. 2. ed. aum. atual. conforme o novo Código Civil (Lei n. 10.406/2002). São Paulo: Saraiva, 2002.

HABERMAS, Jürgen. O futuro da natureza humana. São Paulo: Martins Fontes, 2004.

HIRONAKA, Giselda Maria Fernandes Novaes. Tendências atuais da responsabilidade civil: marcos teóricos para o século XXI. Revista Brasileira de Direito Comparado, Rio de Janeiro, v. 19, p. 189-206, jul./dez. 2001.

JONAS, Hans. El principio de responsabilidad: ensayo de uma ética para la civilización tecnológica. Tradução de Javier Maria Fernández Retenaga. Barcelona: Herder, 1995.

KFOURI NETO, Miguel. Culpa médica e ônus da prova. São Paulo: Editora Revista dos Tribunais, 2002. 
LIMA NETO, Francisco Vieira. Responsabilidade civil das empresas de Engenharia Genética: em busca de um paradigma bioético no Direito Civil. São Paulo: LED Editora de Direito, 1997.

MARTINS-COSTA, Judith; FERNANDES, Márcia Santana; GOLDIM, José Roberto. Lei de Biossegurança - Medusa Legislativa?. Jornal da ADUFRGS, Porto Alegre, n. 134, p. 19-21, maio 2005.

MAZEAU, Henri; MAZEAU, Leon; Tunc, André. Tratado teórico y prático de la responsabilidad civil delictual y contractual. 5. ed. Trad. Juis Alcalá-Sanira y Castillo. Buenos Aires: EJEA, 1962. v. 1.

OLIVEIRA, Simone Born de. Da bioética ao biodireito: manipulação genética e dignidade humana. Curitiba: Juruá, 2002.

PEREIRA, Caio Mario da Silva. Responsabilidade civil. 9. ed. rev. Rio de Janeiro: Forense, 2000.

PLATÃO. A República. 9. ed. Lisboa: Funcação Calouste Gulbenkian, 2001.

RAWLS, John. Uma Teoria da Justiça. São Paulo: Martins Fontes, 2000.

REIS, Clayton. Avaliação do Dano Moral. Rio de Janeiro: Forense, 1998.

REIS, Clayton. Dano Moral. Rio de Janeiro: Forense, 2001.

ROBERTO, Luciana Mendes Pereira. Responsabilidade civil do profissional de saúde \& consentimento informado. Curitiba: Juruá, 2005.

SIQUEIRA, José Eduardo de. Ética e tecnociência: uma abordagem segundo o princípio da responsabilidade de Hans Jonas. Londrina: EDUEL, 1998.

STRECK, Lenio Luiz. Hermenêutica Jurídica e $(m)$ crise. 2. ed. Porto Alegre: Livraria do Advogado, 2000.

TARIFFA, Rita de Cássia Resquetti. A proteção da vida humana pelo direito e a evolução dos direitos fundamentais. In:______. Autonomia corporal e manipulação genética humana. 2004. Dissertação (Mestrado em Direito Negocial) - Universidade Estadual de Londrina, Londrina.

TELLES JUNIOR, Goffredo. Ética: do mundo da célula ao mundo dos valores. 2. ed. rev. São Paulo: Editora Juarez de Oliveira, 2004. 